\title{
Arbuscular Mycorrhizal Technology in Reclamation and Revegetation of Coal Mine Spoils under Various Revegetation Models
}

\author{
Akhilesh Kumar ${ }^{1}$, Richa Raghuwanshi ${ }^{2 *}$, Ram Sanmukh Upadhyay ${ }^{3}$ \\ ${ }^{1}$ Government Degree College, Narnaul, India \\ ${ }^{2}$ Department of Botany, Mahila Mahavidyalaya Banaras Hindu University, Varanasi, India \\ ${ }^{3}$ Department of Botany, Banaras Hindu University, Varanasi, India \\ E-mail:\{akhilesh_100,upadyay_bhu\}@yahoo.co.uk,richabhu@yahoo.co.in \\ Received November 25, 2009; revised July 21, 2010; accepted August 23, 2010
}

\begin{abstract}
Reclamation and revegetation of a coal mine spoils with various revegetation models utilizing the mycorrhizal technology were studied. The models with different combination of plant species were designed to test the hypothesis of speedy revegetation. Root colonization and spore density of arbuscular mycorrhizae (AM) were lowest in plants seeded directly on slopes of the overburden (coal mine dump). At flat surfaces, the mycorrhizal colonization in plant species was higher than that observed at slopes. In other revegetation models, i.e., tree monoculture, tree monoculture + crop species (agroforestry), and two strata plantations (combination of different plant species), maximum AM colonization was recorded for tree species grown along with crop species. This was followed by two strata plantations and tree monoculture. In two strata plantations three categories of AM associations were recognized: 1) every plant in the combination, possessed high mycorrhizal association, 2) only one plant in the combination possessed high mycorrhizal association, and 3) none of the plants in the combination possessed high mycorrhizal association. Azadirachta indica, Pongamia pinnata, Leucaena leucocephala and Acacia catechu were most effective in catching mycorrhizae, and can be used as the effective tool in rehabilitation of the degraded ecosystems.
\end{abstract}

Keywords: Coal Mine Spoils, Reclamation, Revegetation and Mycorrhizae

\section{Introduction}

AM fungi form the fundamental linkage between the biotic and abiotic components of the ecosystem in addition to their being the primary colonizers of coal mine spoils [1-2]. The primary approach to revegetation of such spoils is the erosion control through plant cover in short-term and development of a self-sustaining community through colonization of native plants in the longterm [3]. The soil conservation practices not only make the soil resistant to erosion, but also directly affect the soil pore size distribution [4]. The soil aggregates and pore size collectively constitute 'soil structure' which in turn influences not only the physico-chemical but also the biological processes [5-6]. The contribution of AM fungi to soil aggregate formation can be grouped into three categories according to Miller and Jastrow [7]:
These are: 1) growth of external AM hyphae in the soil matrix to create the skeleton that holds primarily the soil particles (i.e. sand, silt and clays) together via physical entanglement, 2) creation of conditions by roots and external hyphae conducive to formation of microaggregates whereby mineral particles and organic debris are held and cemented together by various physico-chemical events involving binding agents like the persistent gums and glues in the root exudates, the soil microbes and mycorrhizal hyphae in particular contribute hydrophobic glycoprotein glomalin [8], and 3) enmeshment of microaggregates and smaller macroaggregates by external hyphae and roots to form the macroaggregates that can be further stabilized by intermicoraggregate and intermacroaggregate cementation by polysaccharides and other organics from microorganisms and plant roots. These three processes operate simultaneously because of dynamic 
nature of soil aggregation. The improvement in soil aggregation sustains ideal water infiltration, tilth and aeration for plant growth [9].

There are countless reasons to qualify mycorrhizae as bliss for revegetation programmes as infection of plant roots by such fungi induces tolerance against the abiotic and biotic stresses. Mycorrhizal fungi appear to partially protect plants against heavy metal toxicity through binding and thus limiting their translocation to shoots [10]. The host plant in turn may give the fungus a selective survival advantage on a contaminated site. The metal sequestration by AMF may alter their translocation in plants thus restricting metal accumulation in mycorrhizal roots and so also reduce metal transfer to the aboveground biomass [11]. The only direct evidence of mycorrhizal adaptation to metal pollutants is the exudation of complexing organic acids that alter pollutant availability in the rhizosphere [12]. Metallophytes have evolved various physiological adaptations to successfully compete with the harsh conditions in heavy metal loaded soils. In addition, AMF that colonize plant roots, considerably reduce the intake of heavy metals by plant cells that could be one of the strategies that allows metallophytes to thrive on heavy metal polluted sites [13-14]. Haselwandter [15] proposed that a metal-resistant plant breed susceptible to mycorrhizal symbiosis would be of great value for the rehabilitation of metal contaminated soils. AM fungi that modify the root system and play a critical role in the nutrient cycling in the ecosystem, can be taken as a crucial parameter to access reclamation success of degraded lands. Thus, restoration success depends on the augmentation of biological activity of the surface soil horizons [16]. In view of the above, the present study was carried out by developing a revegetation model site at the coal mine spoil site utilizing mycorrhizal technology.

\section{Materials and Methods}

Revegetation model site (RMS) was developed at Jayant Coal Mine situated in Singrauli district of Madhya Pradesh, India. An area of about 9 hectare of fresh overburden was smoothened and flattened by bulldozers for plantations in various models designed. Seedlings raised in nursery by either seeds or cuttings were transplanted at the RMS. In each revegetation model, the plot size was $20 \mathrm{~m} \times 20 \mathrm{~m}$ where the plants were transplanted in pit size of $40 \mathrm{~cm} \times 40 \mathrm{~cm} \times 30 \mathrm{~cm}$ with the spacing of $2 \mathrm{~m} \times$ $2 \mathrm{~m}$. The density of the plants per plot was 100 . Seeds of different plant species were seeded directly by broadcasting in case of direct seedling, whereas in rest of the cases the seedlings raised in nursery were transplanted at
RMS. The combination of plants species in different plots at RMS were as follows:

Direct seeding on slope surface: Seeds of different plant species used in direct seeding on slope surface were Acacia catechu, Azadirachta indica, Leucaena leucocephala, Madhuca indica, Pongamia pinnata, Syzygium cumini, Terminalia arjuna and Terminalia bellirica.

Direct seeding on flat surface: The plant species selected were A. catechu, Acacia nilotica, A. indica, $L$. leucocephala, M. indica, P. pinnata, S. cumini, T. arjuna and Zizyphus jujuba.

Tree monoculture: The species raised in monoculture plots were A. catechu, Albizia lebbeck, A. indica, Dalbergia sissoo, Dendrocalamus strictus, Gmelina arborea, L. leucocephala, Phyllanthus emblica, P. pinnata, Tectona grandis and $T$. bellirica.

Tree monoculture + crop plant (Agroforestry): The leguminous Cajanus cajan was sown in combination with A. lebbeck, A. indica, G. arborea, P. pinnata, T. bellirica and T. grandis. Pennisetum typhoides a nonleguminous crop semi-arid tropics was seeded with combination of $A$. indica, D. sissoo, L. leucocephala and $P$. pinnata.

Two strata plantation: Mixed plantations were raised with the following combinations of leguminous and non-leguminous species: $A$. catechu $+P$. pinnata, $A$. lebbeck $+A$. catechu, A. indica $+P$. emblica, D. strictus + T. grandis, G. arborea $+P$. pinnata, P. pinnata $+T$. bellirica, T. bellirica + G. arborea and T. grandis $+L$. leucocephala.

In all the above models, ground seeding with a leguminous forb Stylosanthes hamata and two grasses namely Pennisetum pedicellatum and Heteropogan contortus was done by broadcasting.

\section{Assessment of AM Association}

Composite samples of soil and roots were collected from each plot and isolation of AM spores was done by wet sieving and decanting methods of Gerdemann and Nicolson [17] and sucrose centrifugation method of Jenkins [18]. The number of AM spores per hundred gram of dry soil was estimated.

The root samples were washed, cut into one $\mathrm{cm}$ segments, and placed in tissue capsule [19]. These were cleared and stained with Chlorazol Black E (CBE) in lactoglycerol following the procedure of Phillips and Hayman [20]. One hundred root segments were randomly selected and mounted on microscopic slides for observation. Quantification of the root colonization is based on percentage of AM colonization. Association of mycorrhizae was based on the presence or absence of 
arbuscules, vesicles and internal hyphae in the root tissue.

\section{Results}

Dynamics of AM in plant roots and rhizosphere soil was studied in various models at the revegeatation site. The models with plantation of various combinations of plant species were designed to test the extent of speedy revegetation of coal mine spoils. The lowest level of mycorrhizal association was found in plants seeded directly on slopes (Figure 1). At flat surfaces, AM colonization in plant roots was higher than that observed at slope surfaces (Figure 2), but it was lesser as compared to other models. A. indica, L. leucocephala, $M$. indica and $P$. pinnata harboured significantly higher level of AM at slopes while it was significantly higher in $A$. catechu, $A$. nilotica, A. indica, L. leucocephala and $P$. pinnata at flat surfaces. In other plants the AM association was poor both at slopes and flat surfaces.

In rest of three revegetation models (i.e., tree monoculture, tree monoculture + crop species and two strata plantations) nursery raised seedling were transplanted at RMS in pits in various combinations. The highest level of AM colonization was recorded for the tree species grown with crop species (agroforsetry) followed by the two strata plantations and tree monoculture. Two species namely $A$. indica, and $D$. sissoo possessed significantly ( $\mathrm{p}=0.01$ ) higher level of AM colonization than others rose in monoculture (Figure 3). The rhizosphere soil of L. leucocephala and $P$. pinnata possessed higher AM spore count than others. When the tree species were seeded along with crop species, the combinations $A$. indica $+C$. cajan, A. indica + P. typhoides and D. sissoo + $P$. typhoides possessed significantly higher $(\mathrm{p}=0.01)$ AM colonization. In the same model, rhizosphere soil of the tree species in combinations $G$. arborea $+C$. cajan and $P$. pinnata $+C$. cajan contained higher AM spore number compared to other combinations (Figure 4). In two strata plantations (Figure 5) three categories of combinations were recognized: 1) each of the plant in the combination possessed high mycorrhizal association (e.g. $G$. arborea $+P$. pinnata and $T$. grandis + L. leucocephala, 2) only one plant of the combination possessed high mycorrhizal association (e.g. A. indica $+P$. embilica and D. strictus $+T$. grandis), and 3) none of the plants in the combination possessed high mycorrhizal association (e.g. A. lebbeck $+A$. catechu and T. bellirica $+G$. arborea). In two strata plantation, the best combinations with high mycorrhizal association were $G$. arborea $+P$. pinnata and T. grandis + L. leucocephala.

AM spore number was higher in the rhizosphere soils of $P$. pinnata and $G$. arborea when grown together on the dumps (Figure 5). In other combinations, either both the plants or one of them possessed lesser degree of AM association. The spore number was higher in the rhizosphere soil of $P$. pinnata as compared to other combinations. A. lebbeck $+A$. catechu, P. pinnata $+T$. bellirica and $T$. bellirica $+G$. arborea were a few of other combinations having poor AM spore counts in their rhizosphere.

Generally, the AM colonization was higher in the roots of leguminous tree species grown with non-leguminous ones in combination (Figure 5). The examples of such combinations were: $T$. grandis $+L$. leucocephala, $G$. arborea $+P$. pinnata and D. strictus $+T$. grandis. A moderate to high AM colonization was recorded in $P$. pinnata for all the combinations tested. Low mycorrhizal colonization was recorded for $A$. lebbeck $+A$. catechu and $T$. bellirica $+G$. arborea combinations.

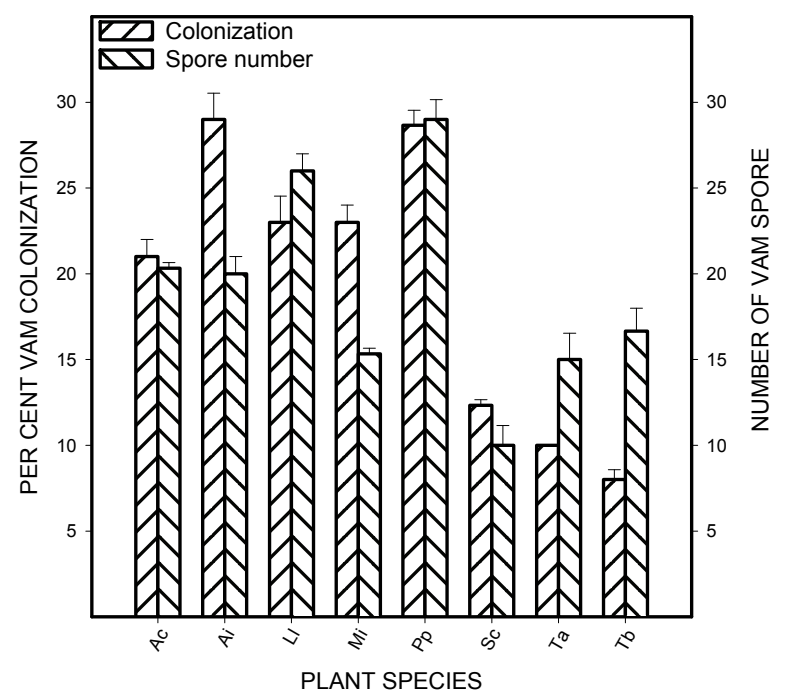

Figure 1. VAM association in plant species grown at slopes by direct see ding at revegetion medel site.

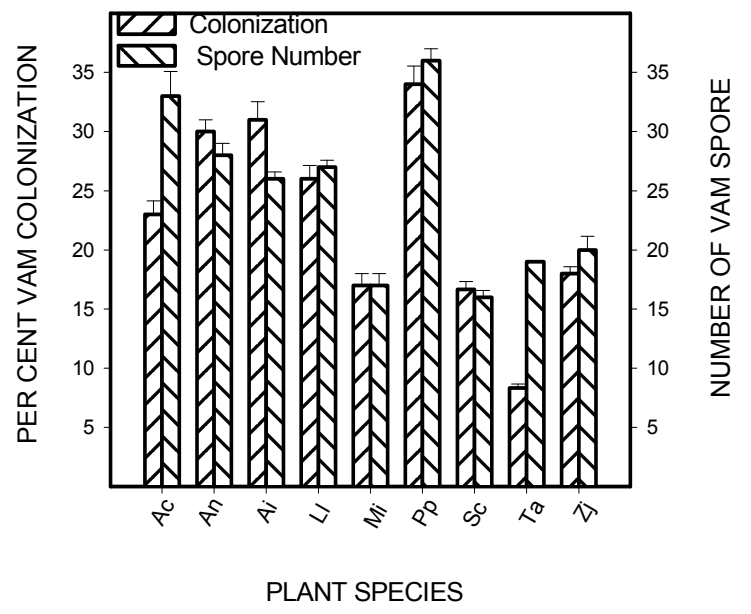

Figure 2. VAM association in plant species grown at flat surface by direct seeding at revegetation model site. 


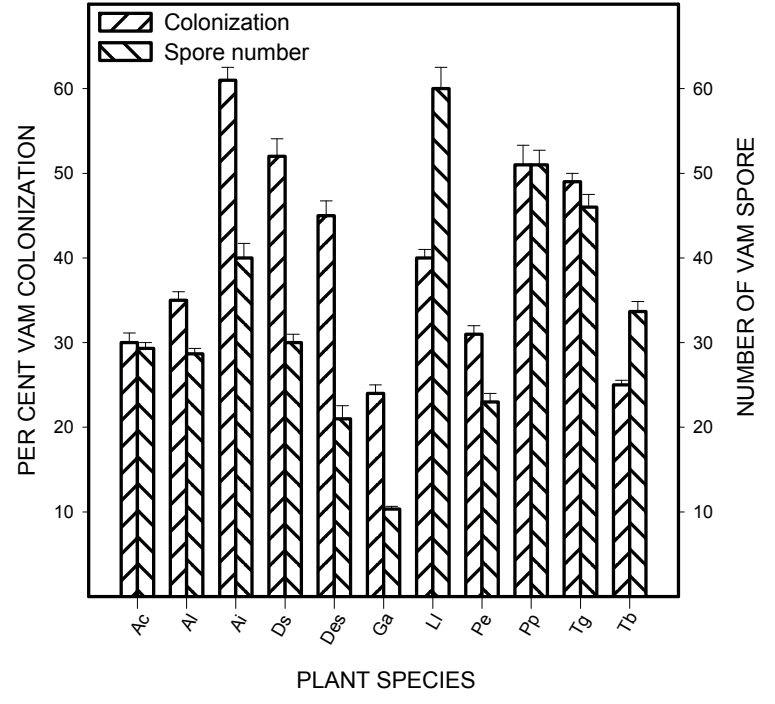

Figure 3. VAM association in plant species in monocuiture at revegetation medel site.

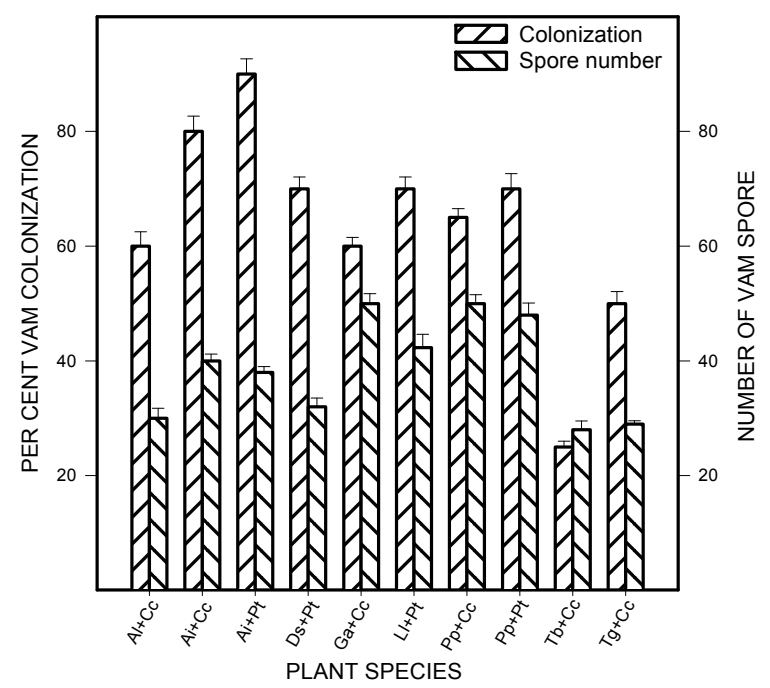

Figure 4. VAM association in plant species planted along with crop species at revegetation model site.

No significant correlation could be established between AM colonization and the spore number. In $T$. grandis (grown with $D$. strictus), P. embilica (grown with $A$. indica), the spore count in the rhizosphere was high but the AM colonization was low. However, in case of $A$. indica (with P. emblica), P. pinnata (with A. catechu), L. leucocephala (with $T$. grandis) and $T$. bellirica (with $P$. pinnata), the spore count was low in the rhizosphere in contrary to high AM colonization in roots. In some species such as $P$. emblica (with $A$. indica), $T$. grandis (with L. leucocephala), A. lebbeck (with A. catechu) and T. bellirica (with G. arborea), the AM colonization as well as spore number both were low. In a few plants, AM colonization as well as spore number was high. These were G. arborea and P. pinnata (grown together) and $P$. pinnata (grown along with $T$. bellirica). Two combinations namely $A$. lebbeck $+A$. catechu and T. bellirica + $G$. arborea possessed low level of AM association.

\section{Discussion}

The present study involved various RMS models for assessment of mycorrhizal status of the plants. AM colonization was poor in plants grown by seeding on overburden both at flat surface and slopes. This may be attributed to poor emergence of roots, as a result of erosion, the detrimental factor affecting survival of plants and poor presence of AM as well. This is supported by the fact that at slopes, where soil erosion was severe, the AM-plant association in plants was poor. The nursery raised seedlings as monoculture favored mycorrhization than the direct seeding. High AM colonization was recorded in P. pinnata, L. leucocephala and D. strictus in two strata plantation. Seeding or planting of species not only controls erosion but also enhances species diversity and speeds up succession that meets the revegetation goal. Nicholasan and McGinnies [21] reported that establishment of good plant cover can stabilize mine spoil and consequently improve soil conditions to promote plant succession [22]. Direct seeding of plants has been recommended in many reports [23-25]. There are reports that seedling growth and survival of tree species is affected by seeding of grasses and legumes [26]. The grasses are beneficial in checking erosion while legumes improve soil nutrient status. AM fungi benefit plant establishment and survival in many ways in degraded lands [27-30], and restoration programs with application mycorrhizal technology have been successful [31-32].

Agroforestry is the collective term for land use system wherein woody perennials are grown in association with agricultural herbaceous plants, following spatial arrangement or temporal sequence that facilitates both ecological and economic interactions between the tree and non-tree components. In mixed plantations, it appeared that leguminous plants were more advantageous than non-leguminous trees except $A$. indica. Tree + crop plantation appeared to be the best model in terms of mycorrhizal technology at least for the selected species. $A$. indica, $P$. pinnata, L. leucocephala and A. catechu were most effective in attracting luxuriant mycorrhizae (even when seeded directly), and thus can be used as the suitable rehabilitating species in such degraded ecosystems. It seems that seeding with grasses and leguminous forbes increased AM inoculums, as these grew luxuriantly with fibrous roots that favored mycorrhizal association. Leguminous shade trees contribute substantial $\mathrm{N}$ to the understory crop growth and also favors $\mathrm{N}$ uptake by tropi- 


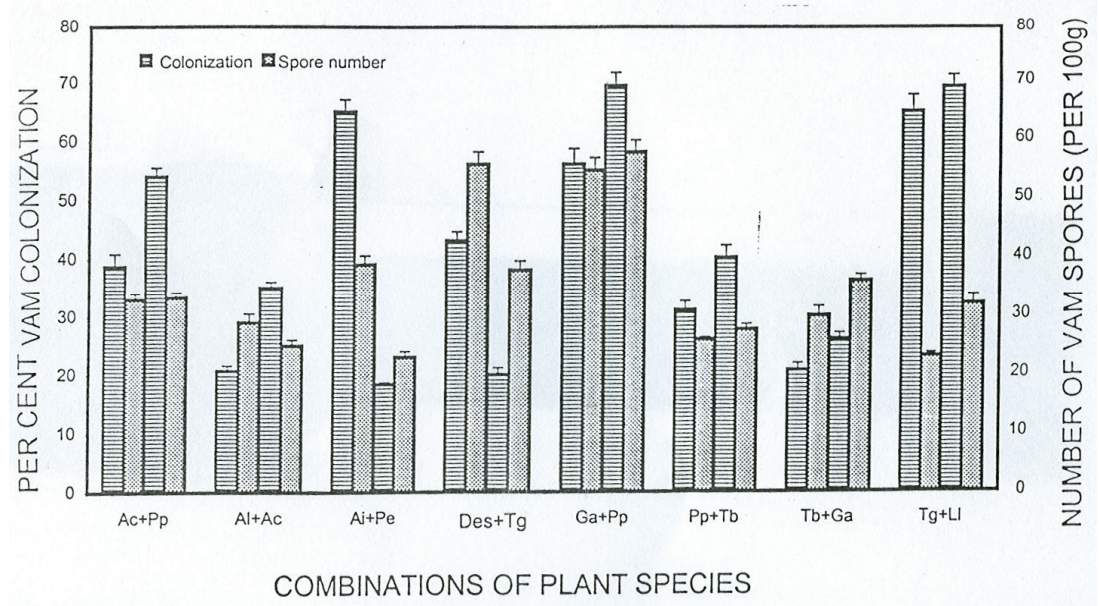

Figure 5. VAM association in plant species grown in two strata plantation at revegetating model site. Abbreviationa: Ac, $A$. catechu; Al, $A$. lebbeck; Ai, $A$. indica; Ds D. sissoo; Des, D. strictus; Ga, G. arborea; Li, L lencocephala; Pe, P. emblicar; Pp, P. pinnata; Tg, T. grandis, Tb, T. bellerica.

cal grasses [33-34]. Further, the results confirm the fact that mycorrhizae also help the plant-soil-plant system by inter-bridging between the roots of different plants [3537].

Most legumes are fairly responsive to and extensively colonized by mycorrhizae especially in soils where an insufficiency of available P limits plant growth. Hence, the influence of mycorrhizae on legumes is potentially greater over any other group because of alleviation of P-stress by symbiotic fungi and indirectly by enhancing $\mathrm{N}$ status soil contributed by the legumes. Since plants do not contain their own polyphosphate hydrolase, they rely on the activity of soil microorganisms to release free phosphate from minerals or organic $\mathrm{P}$ resources. Mycorrhizal plants can utilize more phosphorus than the non-mycorrhizal ones, mainly from the same soluble phosphate pool as AM fungi harbor phosphate transfer [38]. Davies and Call [39] reported that AM significantly enhance the nutritional status in perennial grasses growing at lignite overburden. The successful restoration depends on the capacity of the plants to capture resources at an early stage. On degraded lands, which may be droughty, nutritionally poor or otherwise stressed, there exists only a brief period favorable period for plant growth and the plants which do not establish within that time window fail to survive.

Jeffries et al. [40] also supported the persistence of an acceptable amount of weeds within crops; providing a reservoir of mycorrhizal inoculum. Established mycorrhizal vegetation can facilitate the probability or extent of mycorrhizal infection of seedlings and thus mycorrhizal interaction among distantly related plants might be of particular ecological interest, as this may permit early succession of plants [41].

\section{Acknowledgements}

The research project was funded by the Ministry of Coal, Government of India through Central Mine Planning and Design Institute Limited (CMPDI), Ranchi, India. The financial assistance in the form of Junior and Senior Research Fellowship is gratefully acknowledged.

\section{References}

[1] E. G. O’ Neill, R. V. O' Neill and R. J. Norby, “Hierarchy Theory as a Guide to Mycorrhizal Research on Large-Scale Problems," Environmental Pollution, Vol. 73, No. 3-4, 1991, pp. 271-284.

[2] B. F. Rodrigues, "Diversity of Arbuscular Mycorrhizal (AM) Fungal Species from Iron Ore Mine Wastelands in Goa," The Indian Forester, Vol. 126, No. 11, 2000, pp. 1211-1215.

[3] W. W. Mitchell, "Revegetation Research on Coal Mine Overburden Materials in Interior to Southeastern Alaska," Agriculture and Forest Experimental Station Bulletin, Vol. 79, 1987, pp. 72-86.

[4] W. W. Emerson, R. C. Foster and J. M. Oades, "OrganoMineral Complexes in Relation to Soil Aggregation and Structure," In: P. M. Huang and M. Schnitzer, Eds., Interactions of Soil Mineral with Natural Organics and Microbes, SSSA Special Publication, Madison, Vol. 17, 1986, pp. 521-548.

[5] D. C. Coleman, "The Role of Microfloral and Faunal Interactions in Affecting Soil Processes. In: M. J. Mitchell and J. P. Nakes, Eds., Microfloral and Faunal Interactions in Natural and Agro-Ecosystems, W. Junk Publishers, Boston, 1986, pp. 317-348.

[6] T. T. Elliot and D. C. Coleman, "Let the Soil Work for us," Ecological Bulletin, Vol. 39, No. 2-3, 1988, pp. 2332. 
[7] R. M. Miller and J. D. Jastrow, "Mycorrhizal Fungi Influence Soil Structure," In: Y. Kapulnik and D. D. Douds, Eds., Arbuscular Mycorrhizas: Physiology and Function, Kluwer Academic, Dordrecht, The Netherlands, 2000, pp. 3-18.

[8] M. C. Gonzalez-Chavez, R. Carrillo-Gonzalez, S. F. Wright and K. Nichols, "The Role of Glomalin, a Protein Produced by Arbuscular Mycorrhizal Fungi in Sequestering Potentially Toxic Elements," Environmental Pollution, Vol. 130, No. 3, 2004, pp. 317-323.

[9] S. F. Wright and A. Upadhyaya, "A Survey of Soils for Aggregate Stability and Glomalin, a Glycoprotein in Produced by Hyphae of Arbuscular Mycorrhizal Fungi," Plant and Soil, Vol. 198, No. 1, 1998, pp. 97-107.

[10] T. Selvaraj, P. Chellapan, Y. J. Jeong and H. Kim, "Occurrence and Quantification of Vesicular Arbuscular Mycorrhizae Fungi in Industrial Polluted Soils," Journal of Microbiology and Biotechnology, Vol. 15, No. 1, 2005, pp. 147-154.

[11] T. E. Pawlowska, L. C. Rufus, M. Chin and I. Charvat, "Effects of Metal Phytoextraction Practices on the Indigenous Community of Arbuscular Mycorrhizal Fungi at a Metal Contaminated Landfill," Applied Environmental Microbiology, Vol. 66, No. 6, 2000, pp. 2526-2530.

[12] A. A. Meharg, "The Mechanistic Basis of Interactions between Mycorrhizal Associations and Toxic Metal Cations," Mycological Research, Vol. 107, No. 11, 2003, pp. 1253-1265.

[13] F. Quizad, U. Hilderbrandt, E. Schmelzer and H. Bothe, "Differential Gene Expressions in Arbuscular Mycorrhizal-Colonized Tomato Grown under Heavy Metal Stress," Journal of Plant Physiology, Vol. 162, No. 3, 2005, pp. 634-649.

[14] K. Vogel-Mikus, P. Pongrac, P. Kump, M. Necemer and M. Regvar, "Colonization of a $\mathrm{Zn}, \mathrm{Cd}$ and $\mathrm{Pb}$ Hyperaccumulator Thlaspi praecox Wulfen with Indigenous Arbuscular Mycorrhizal Fungal Mixture Induces Changes in Heavy Metal and Nutrient Uptake," Environmental Pollution, Vol. 139, No. 2, 2006, pp. 362-371.

[15] K. Haselwandter, "Soil Microorganisms, Mycorrhiza and Restoration Ecology," In: K. M. Urbanska, N. R. Webb and P. J. Edwards, Eds., Restoration Ecology and Sustainable Development, Cambridge University Press, Cambridge, 1997.

[16] P. W. Arnold, A. Gildon and D. L. Rimmer, "The Use of Soil in the Reclamation of Coal Mine Wastes," Proceedings of the Symposium on the Reclamation, Treatment and Utilization of Coal Mining Wastes, Durham, England, 1984, pp. 26.1-26.10.

[17] J. W. Gerdemann and T. H. Nicolson, "Spores of Mycorrhizal Endogone Species Extracted from Soil by Wet Sieving and Decanting," Transactions of British Mycological Society, Vol. 46, No. 2, 1963, pp. 235-244.

[18] B. A. Daniels and H. D. Skipper, "Methods for the Recovery and Quantitative Estimation of Propagules from Soil," In: N. C. Schenck, Ed., Methods and Principles of Mycorrhizal Research, American Phytopathological Society, Vol. 29, St. Paul, Minnesota, 1982, pp. 29-36.
[19] P. P. Kormanik, W. C. Bryan and R. C. Schultz, "Increasing Endomycorrhizal Fungus Inoculum in Forest Nursery Soil with Cover Crops," South African Journal of Applied Forestry, Vol. 4, 1980, p.151.

[20] J. M. Phillips and D. S. Hayman, "Improved Procedures for Clearing and Staining Parasitic and Vesicular Arbuscular Mycorrhizal Fungi for Rapid Assessment of Infection," Transactions of British Mycological Society, Vol. 55,1970 , pp. 158-161.

[21] E. J. Nicholasan and W. J. Mc Ginnies, "An Evaluation of Seventeen Grasses and Two Legumes for Revegetation of Soil and Spoil on a Coal Strip-Mine," Journal of Range Management, Vol. 35, No. 1, 1982, pp. 288-293.

[22] W. M. Schafer and G. A. Nielsen, "Soil Development and Plant Succession on 1-to-50-yr-Old Strip Mine Spoils in Southern Montana," In: M. K. Wali, Ed., Ecology and Coal Resource Development, Vol. 2, Pergamon Press, New York, 1979, pp. 541-549.

[23] W. H. Davidson, "Direct Seeding for Reforestation," In: Trees for Reclamation, USDA Forest Service General Technical Report, NE-61, 1980, pp. 93-97.

[24] R. F. Wittwer, S. B. Carpenter and D. H. Graves, "Survival and Growth of Oakes and Virginia Pine Three Years after Direct Seeding on Mine Spoils," In: Proceedings of the Symposium on Surface Mining Hydrology, Sedimentology and Reclamation, University of Kentucky, Lexington, Kentucky, 1981, pp. 1-4.

[25] J. L. Creighton, R. N. Muller and R. F. Wittwer, "Biomass and Nutrient Assimilation of Intensively-Cultured Black-Locust on Eastern Kentucky Mine Spoil," Proceedings of the Symposium on Surface Mining, Hydrology, Sedimentology and Reclamation, University of Kentucky, Lexington, Kentucky, 1983, pp. 503-508.

[26] T. R. Cunningham and R. F. Wittwer, "Direct Seeding of Oaks and Black Walnut on Mine Soils in Eastern Kentucky," Reclamation and Revegetation Research, Vol. 3, 1984, pp. 173-184.

[27] M. C. Brundrett, "Mycorrhizas in Natural Ecosystem," Advances in Ecological Research, Vol. 21, 1991, pp. 171173.

[28] A. Varma, "Ecophysiology and Application of Arbuscular Mycorrhizal Fungi in Arid Soils," In: A. Varma and B. Hock, Eds., Mycorrhiza, Structure, Function, Molecular Biology and Biotechnology, Sprintger-Verlag, Berlin, Heidelberg, 1995, pp. 561-591.

[29] A. Gaur and A. Adholeya, "Prospects of AM Fungi in Phytoremediation of Heavy Metal Contaminated Soils: Mini Review," Current Science, Vol. 86, No. 4, 2003, pp. 528-534.

[30] R. Raghuwanshi and R. S. Upadhyay, "Performance of Vesicular-Arbuscular Mycorrhizae in Saline-Alkali Soil in Relation to Various Amendments," World Journal of Microbiology and Biotechnology, Vol. 20, No. 1, 2004, pp. 1-5.

[31] D. H. Marx, "Trials and Tribulations of an Ectomycorrhizal Fungus Inoculation Program," Proceedings of 6th North American Conference on Mycorrhizae, Forest 
Research Laboratory, Oregon State University, Corvallis, 1985, pp. 62-63.

[32] C. E. Cordell, "The Application of Pisolithus tinctorius Ectomycorrhizae in Forest Land Management," Proceedings of 6th North American Conference on "Mycorrhizae", Forest Research Laboratory, Oregon State University, Corvallis, 1985, pp. 69-72.

[33] C. C. Wong and J. R. Wilson, "The Effect of Shading on the Growth and Nitrogen Content of Green Panic and Sirato in Pure and Mixed Swards Defoliated at Two Frequencies," Australian Journal of Agricultural Research, Vol. 31, No. 2, 1980, pp. 269-285.

[34] F. I. Eriksen and A. S. Whitney, "Effect of Light Intensity on Growth of Some Tropical Forage Species 1. Interactions of Light Intensity and Nitrogen Fertilization on the Six Forage Grasses," Agronomy Journal, Vol. 73, No. 3, 1981, pp. 427-433.

[35] E. I. Newman, "Mycorrhizal Links between Plants: Their Functioning and Ecological Significance," Advances in Ecological Research, Vol. 18, 1988, pp. 243-270.

[36] E. I. Newman and W. R. Eason, "Cycling of Nutrients from Dying Roots to Living Plants Including the Role of Mycorrhizas," In: L. Clarholm and L. Bergstrom, Eds.,
Ecology of Arable Land, Kluwer, Dordrech, 1989, pp. 133-137.

[37] W. R. Eason and E. I. Newman, "Rapid Cycling of Nitrogen and Phosphorus from Dying Roots of Lolium perenne," Oecologia, Vol. 82, No. 4, 1990, pp. 432-436.

[38] T. Selvaraj and P. Chellapan, "Arbuscular Mycorrhizae: A Diverse Personality," Journal of Central European Agriculture, Vol. 7, No. 2, 2006, pp. 349-358.

[39] F. T. Davies, Jr. and C. A. Call, "Survival and Growth of Mycorrhizal Woody Revegetation Species in Texas Lignite Overburden," Proceedings of the 7th North American Conference on Mycorrhizae in the Next Decade, Gainesville, Florida, 1987, p. 148.

[40] P. Jeffries, S. Gianinazzi, S. Perotto, K. Turnau and J. M. Barea, "The Contribution of Arbuscular Mycorrhizal Fungi in Sustainable Maintenance of Plant Health and Soil Fertility," Biology and Fertility of Soils, Vol. 37, 2003, pp. 1-16.

[41] I. A. Dickie, J. Oleksyn, P. B. Reich, P. Karolewski, R. Zytowiak, A. M. Jagodzinski and E. Turzanska, "Soil Modification by Different Tree Species Influences the Extent of Seedling Ectomycorrhizal Infection," $M y$ corrhizae, Vol. 16, No. 2, 2006, pp. 73-79. 